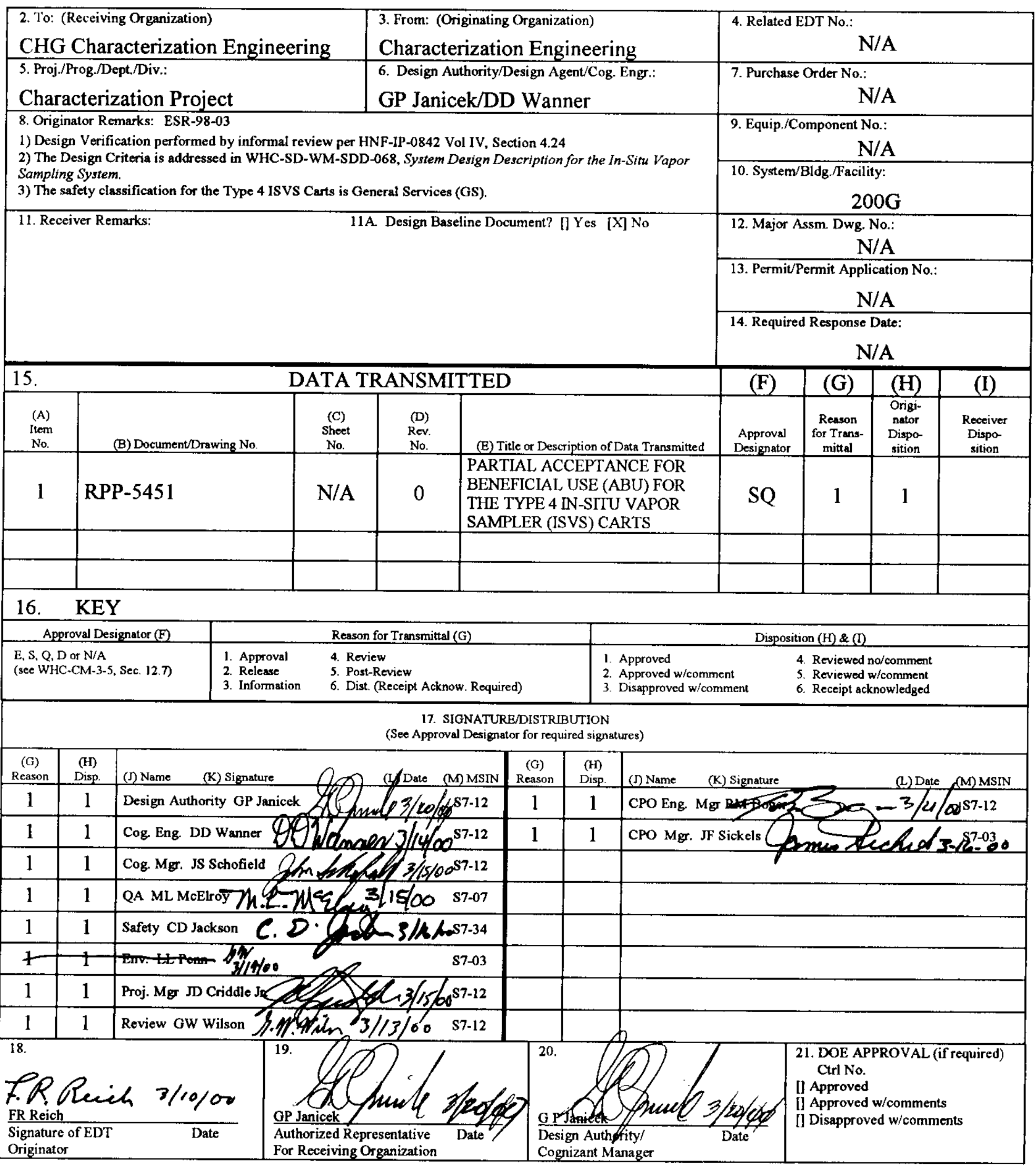




\section{PARTIAL ACCEPTANCE FOR BENEFICIAL USE (ABU) FOR THE TYPE 4 IN-SITU VAPOR SAMPLER (ISVS) CARTS}

R. M. BOGER

CH2M HILL Hanford Group, Inc., Richland, WA 99352

U.S. Department of Energy Contract DE-AC06-96RL13200

EDT/ECN: 624175

Org Code: 74900

B\&R Code: EW3130000
UC: 2000

Charge Code: $102254 / \mathrm{E} 100$

Total Pages: 12

Key Words: Partial, Acceptance for Beneficial Use, ABU, single shell tanks, storage tanks, radioactive waste, vapor sampling, design requirements, Type 4, In-Situ Vapor Sampling, ISVS

Abstract: This document provides the "Partial" Acceptance for Beneficial Use (ABU), for the Type 4 in-situ vapor sampler system (ISVS). This document is generated to support the completion of equipment modifications and engineering documentation for the ISVS system that is used for sampling gaseous vapors in the Hanford single shell radioactive waste storage tanks. The ABU is used to document the items required for transferring the ISVS system to operations for field use. This document is generated following Characterization Engineering Desk Instruction DI-CE-004-001.

TRADEMARK DISCLAIMER. Reference herein to any specific commercial product, process, or service by trade name, trademark, manufacturer, or otherwise, does not necessarily constitute or imply its endorsement, recommendation, or favoring by the United States Government or any agency thereof or its contractors or subcontractors.

Printed in the United States of America. To obtain copies of this document, contact: Document Control Services, P.O. Box 950, Mailstop H6-08, Richland WA 99352, Phone (509) 372-2420; Fax (509) 376-4989.
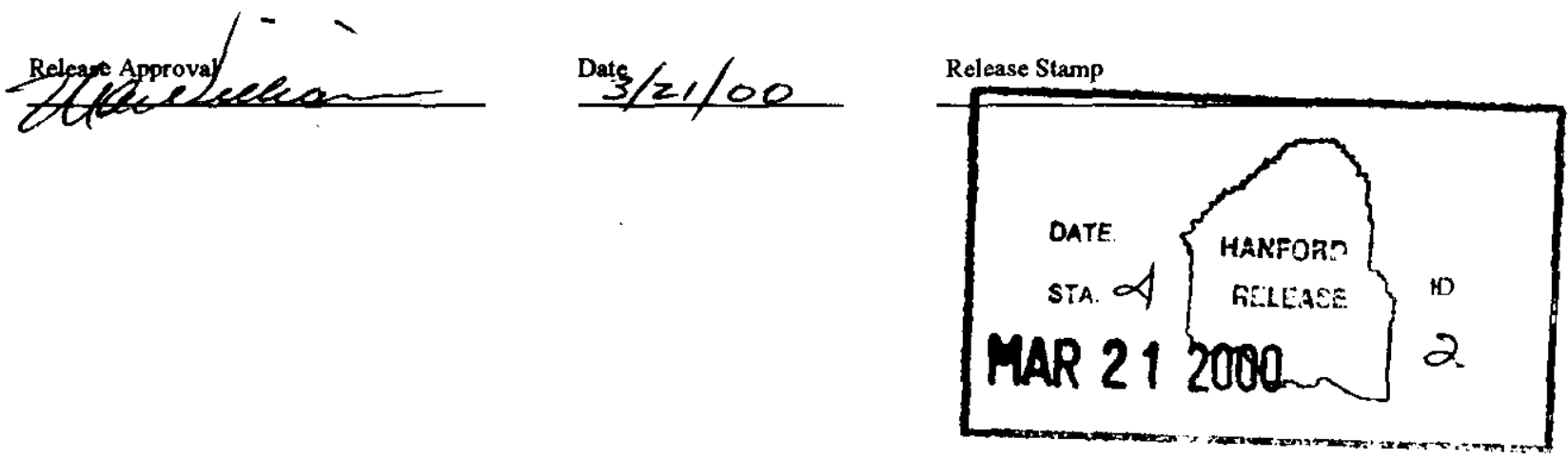

Approved for Public Release 


\title{
PARTIAL ACCEPTANCE FOR BENEFICIAL USE (ABU) FOR THE TYPE 4 IN-SITU VAPOR SAMPLER (ISVS) CARTS
}

\author{
Prepared For \\ River Protection Project \\ CH2M HILL Hanford Group, Inc. \\ Characterization Engineering \\ Richland, WA
}

By G. W. Wilson

COGEMA Engineering Corporation

Richland, Washington

March 2000 


\section{TABLE OF CONTENTS}

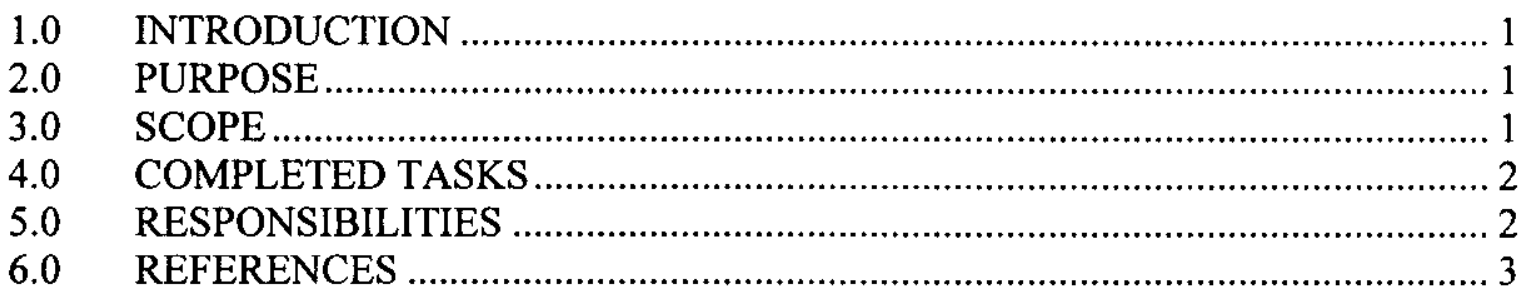

\section{APPENDICES}

Appendix A............................................................ 


\section{PARTIAL ACCEPTANCE FOR BENEFICIAL USE (ABU) FOR \\ TYPE 4 IN-SITU VAPOR SAMPLER (ISVS) CARTS}

\subsection{INTRODUCTION}

This document presents the "Partial" Acceptance For Beneficial Use (ABU) for the Type 4 In Situ Vapor Sampling system carts that were updated for use during FY-2000. The two existing Type 4 carts (ISVS-1 and ISVS-2) have been in storage and have not been used for over two years. A task was initiated to upgrade the ISVS Type 4 sampling carts and ready them for field deployment (RPP 2000a).

The Type 4 ISVS carts are portable sampling systems designed to collect in-tank vapor samples from the head space region of Hanford's radioactive waste storage tanks (WHC 1996). The Type 4 ISVS system consists of a cart, a tube bundle, and a sampling head. The cart contains an instrumentation cabinet with vacuum air pump components, a manifold and various valves, flow meters, flow totalizers, rotameters, and filters mounted on a hand truck. The tube bundle (approximately $50-\mathrm{ft}$ long) connects the cart with the sampling head and is used to lower the sampling head into a tank dome space through a tank riser. The sampling head contains particulate filters, tritium-trap filters, multiple sorption tubes, and a thermocouple. As tank dome-space gas is drawn through the tube bundle by the cart vacuum system, the sampling head scavenges particle and gas samples. The selection and arrangement of the sorption tubes and filters is dependent upon the vapor sampling needs identified in the Data Quality Objective document (LMHC 1999a) and the sampling analysis plan (SAP). After sampling is completed the sample head is disconnected from the tube bundle, bagged out with protective plastic, and shipped to the $222 \mathrm{~S}$ laboratory for analysis.

\subsection{PURPOSE}

This "Partial" $\mathrm{ABU}$ documents the completion of items that are required prior to turnover of the Type 4 ISVS system to Operations for field deployment. This ABU was completed as required by HNF-IP-0842, Section 3.12, "Acceptance of Structures, Systems, and Components for Beneficial Use" and supports configuration management of the Type 4 ISVS system (LMHC $1999 \mathrm{~b}$ ). This is a "Partial" ABU in that several non-critical items remain to be completed. This "Partial" ABU allows the Type 4 ISVS system to be field deployed to support FY 2000 vapor sampling and mixer pump testing schedules. None of the remaining ABU items have an impact on the operation or safety of the Type 4 ISVS system.

\subsection{SCOPE}

This "Partial" ABU documents the completed tasks and identifies documentation that was generated for the turnover of the Type 4 ISVS system to Operations (RPP 2000b).

Appendix A contains the ABU checklist. Appendix A also identifies the items remaining to be completed for the release of a final $A B U$. A final $A B U$ will be completed by revising this 
RPP-5451, Rev. 0

turnover-supporting document via the ECN process after the open documentation is completed and the ECN's incorporated into the system drawings,

\subsection{COMPLETED TASKS}

The tasks and documentation that were completed for the Type 4 ISVS carts includes the following:

- Engineering Task Plan released and issued (RPP-5468).

- Design Compliance Matrix released and issued (RPP 5275).

- Operation Test Procedure released and issued (RPP 5659).

- Updated all ISVS drawings to incorporate old outstanding ECNs.

- Updated sampler head drawing to include potential sampling materials (sorbent tubes, filters, sampler head configuration, etc.) that could be part of a sampling head inserted the tank dome space (H-2-825301).

- Flammable Gas Equipment Advisory Board (FGEAB) approval obtained for dome intrusive vapor sampling with the Type 4 ISVS system per Ignition Control Set $\# 2$ in Facility Group 1, 2, and 3 tanks (FGEAB-97-008, Rev. 8).

- Completed an informal walk-down of Carts \#1 and \#2 (RPP 5468).

- Released 8 modification work ECNs to modify sample cylinder, add digital thermometer, add intrinsically safe thermocouple reader, add fan switch, add totalizer brackets, add stiffening angle, add wire and equipment labels, and add electrical connection diagram for ISVS-2 to show differences that exist between ISVS-1 and ISVS-2 (H2-825301, H2-825313, and H2-825314).

- Completed OTP testing with both ISVS-1 and ISVS-2 (RPP 5911 and RPP 5912).

- Completed operator training (Training Plan Document Number 79600-00-002).

- Updated operating procedures (TO-080-627, Rev. B-0).

- Performed validation and verification of operating procedures (TO-080-627, Rev. B-0).

- Completed NEC inspection (NEC Service Inspection Authorization No. 8175 and 8176).

As indicated in Appendix A, three activities remain to be completed. These tasks are not related to the operability or safety of the Type 4 ISVS system and therefore, the carts are considered ready for field deployment.

\subsection{RESPONSIBILITIES}

The assigned Design Authority is responsible for proper preparation and maintenance of the $\mathrm{ABU}$ and exercises ownership of it on behalf of Characterization Equipment Engineering and Characterization Project Operations management. 


\subsection{REFERENCES}

RPP-5451, Rev. 0

FGEAB-97-008, Rev. 8, Flammable Gas Equipment Advisory Board Interpretation/Recommendation Report, January 12, 2000, CH2M HILL Hanford Group. Richland, Washington.

LMHC 1999a, HNF-SD-WM-DQO-021, Rev. 1, Data Quality Objectives for Regulatory Requirements for Hazardous and Radioactive Air Emissions Sampling and Analysis. Lockheed Martin Hanford Corporation, Richland, Washington, July 1999.

LMHC 1999b, HNF-IP-0842, Vol. IV, TWRS Administrative Procedures, Engineering, Lockheed Martin Hanford Corporation, Richland, Washington, September 1998.

RPP 2000a, RPP-5468, Rev. 0, Engineering Task Plan for Preparing the Type IV In-Situ Vapor Samplers (ISVS) for Use, January 2000, CH2M HILL Hanford Group. Richland, Washington.

RPP 2000b, RPP 5275, Rev. 0, Baseline Design Compliance Matrix for the Type 4 In-Situ Vapor Samplers (ISVS), January 2000, CH2M HILL Hanford Group. Richland, Washington.

RPP 2000c, RPP 5659, Rev. 0, Operations Test Plan for the Type 4 In-Situ (ISVS) System, January 2000, CH2M HILL Hanford Group. Richland, Washington.

RPP 2000d, RPP 5911, Rev. 0, Cart \#2 Type 4 In-Situ Vapor Sampling (ISVS) System Operability and Operational Test Report, March 2000, CH2M HILL Hanford Group. Richland, Washington.

RPP 2000e, RPP 5912, Rev. 0, Cart \#1 Type 4 In-Situ Vapor Sampling (ISVS) System Operability and Operational Test Report, March 2000, CH2M HILL Hanford Group. Richland, Washington.

TO-080-627, Rev. B-0, Vapor Sampling of Waste Tanks Using In-Situ Vapor Sampling (ISVS) System, February 2000, Tank Farm Plant Operating Procedure, CH2M HILL Hanford Group. Richland, Washington.

WHC 1996, Blanchard, R. J., WHC-SD-WM-SDD-068 Rev. 0, System Design Description for the In-Situ Vapor Sampling System, July 1966, Westinghouse Hanford Company, Richland, Washington. 
RPP-5451, Rev. 0

APPENDIX A

ACCEPTANCE FOR BENEFICIAL USE CHECKLIST

A-1 


\begin{tabular}{|c|c|c|c|c|c|}
\hline \multicolumn{6}{|c|}{ ACCEPTANCE FOR BENEFICIAL USE (ABU) } \\
\hline 3. Document No. & $\begin{array}{l}\text { 4. Project } \\
\text { No. }\end{array}$ & $\begin{array}{l}\text { 5. SSC } \\
\text { Designator }\end{array}$ & $\begin{array}{l}\text { 6. System / Building } \\
\text { / Facility }\end{array}$ & $\begin{array}{l}\text { 7. Equipment/ } \\
\text { Component No. }\end{array}$ & \\
\hline RPP-5451 & NA & GS & 200 General & ISVS Carts \#1 & EDT 627877 \\
\hline \multicolumn{3}{|c|}{ Partial ABU ( $X$ ) } & \multicolumn{3}{|c|}{ 10. ATP Rerun Required } \\
\hline \multirow{2}{*}{\multicolumn{6}{|c|}{$\begin{array}{l}\text { 11. Description of Work } \\
\text { Modify Type } 4 \text { ISVS carts by replacing dial thermometer, replacing power strip, and other minor modifications. } \\
\text { Complete update of drawings to represent an as-built condition of each cart. } \\
\text { This partial ABU documents the completion of all activities necessary for the deployment of the two Type } 4 \text { ISVS } \\
\text { carts (Ref ES-00-00032 and ES-00-00033). All items required prior to meet final ABU requirements are completed } \\
\text { except for two items listed below in block } 12 \text {. }\end{array}$}} \\
\hline & & & & & \\
\hline \multicolumn{2}{|c|}{ 12. Description of Work to be Completed } & $\begin{array}{l}\text { 13. Scheduled } \\
\text { Completion } \\
\text { Date }\end{array}$ & $\begin{array}{l}\text { 14. Responsibility for } \\
\text { Completion }\end{array}$ & \multicolumn{2}{|c|}{ 15. Impact on Operations/Safety } \\
\hline \multicolumn{2}{|c|}{$\begin{array}{l}\text { Drawings } \mathrm{H}-2-825301, \mathrm{H}-2- \\
825313 \text {, and } \mathrm{H}-2-825314 \text { to be } \\
\text { revised with ECNs incorporated } \\
\text { following completion of } \\
\text { modifications to cart \#2 }\end{array}$} & $5 / 30 / 2000$ & G. W. Wilson & \multicolumn{2}{|c|}{$\begin{array}{l}\text { No impact on operation or } \\
\text { safety. Configuration control } \\
\text { maintained by approved ECNs } \\
\text { which apply to Sample Carts } 1 \\
\text { and } 2 \text {. }\end{array}$} \\
\hline \multicolumn{2}{|c|}{ Establish Vendor file. } & $5 / 30 / 2000$ & GW Wilson & \multicolumn{2}{|c|}{$\begin{array}{l}\text { No impact on operation or } \\
\text { safety. Required for } \\
\text { configuration control. }\end{array}$} \\
\hline
\end{tabular}




\begin{tabular}{|c|c|c|c|c|c|}
\hline \multicolumn{2}{|c|}{ 16. Documents or Other Items/Tasks to be Updated } & $\begin{array}{l}\text { 17. Fund } \\
\text { Source }\end{array}$ & 18. Doc \# & $\begin{array}{l}19 . \\
\text { Responsibility } \\
\text { for Completion }\end{array}$ & $\begin{array}{l}20 . \\
\text { Required } \\
\text { prior to } \\
\text { final ABU } \\
(\text { Yes/No) }\end{array}$ \\
\hline \multicolumn{6}{|c|}{ ENGINEERING: } \\
\hline - & Engineering Procedure & & & & \\
\hline - & Engineering Task Plan (ETP) $\quad(X)$ & & $\begin{array}{l}\text { RPP-5468, Rev. } 0 \text {, issued } \\
1 / 6 / 00\end{array}$ & FR Reich & Yes \\
\hline - & Final Safety Analysis Report (FSAR) & & & & \\
\hline - & Safety Assessment (SA) & & & & \\
\hline - & Functional Design Criteria (FDC) & & & & \\
\hline - & Conceptual Design Report (CDR) & & & & \\
\hline - & $\begin{array}{l}\text { Supplemental Design Requirements Document } \\
\text { (SDRD) }\end{array}$ & & & & \\
\hline • & System Design Description (SDD) $\quad$ (N/A) & & & & \\
\hline • & $\begin{array}{l}\text { Acceptance Test Procedures (ATPs) and Final } \\
\text { Test Report }\end{array}$ & & & & \\
\hline • & $\begin{array}{l}\text { Operational Test Procedures (OTP) and Final Test } \\
\text { Report }\end{array}$ & & $\begin{array}{l}\text { RPP } 5659, \text { OTP issued } \\
1 / 31 / 00 \text {, and RPP } 5911 \\
\text { (ISVS-2) and RPP } 5912 \\
\text { (ISVS-1) OTRs issued } \\
3 / 2 / 00 \text { per Work packages } \\
\text { ES-00-00032 (ISVS-1) } \\
\text { and ES-00-00033 (ISVS- } \\
\text { 2). }\end{array}$ & DD Wanner & Yes \\
\hline - & Safety Equipment List (SEL) & & $\begin{array}{l}\text { The DCM document } \\
\text { (RPP-5275; Rev. 0) } \\
\text { defines the Type } 4 \text { ISVS } \\
\text { carts as General Service. }\end{array}$ & JD Criddle & Yes \\
\hline - & Environmental Impact Statement & & & & \\
\hline - & Environmental Report & & & & \\
\hline - & Environmental Permits & & & & \\
\hline - & Stress/Seismic Analysis & & & & \\
\hline - & Stress/Design Report & & & & \\
\hline - & Equipment Specification & & & & \\
\hline - & Procurement Specification & & & & \\
\hline - & Construction Specification & & & & \\
\hline - & Essential Material Specification & & & & \\
\hline - & Technical Specification & & & & \\
\hline - & Interface Control Drawing & & & & \\
\hline • & Design Compliance Matrix (DCM) & & $\begin{array}{l}\text { RPP-5275, Rev. 0, issued } \\
1 / 25 / 00\end{array}$ & FR Reich & Yes \\
\hline
\end{tabular}


RPP-5451, Rev. 0

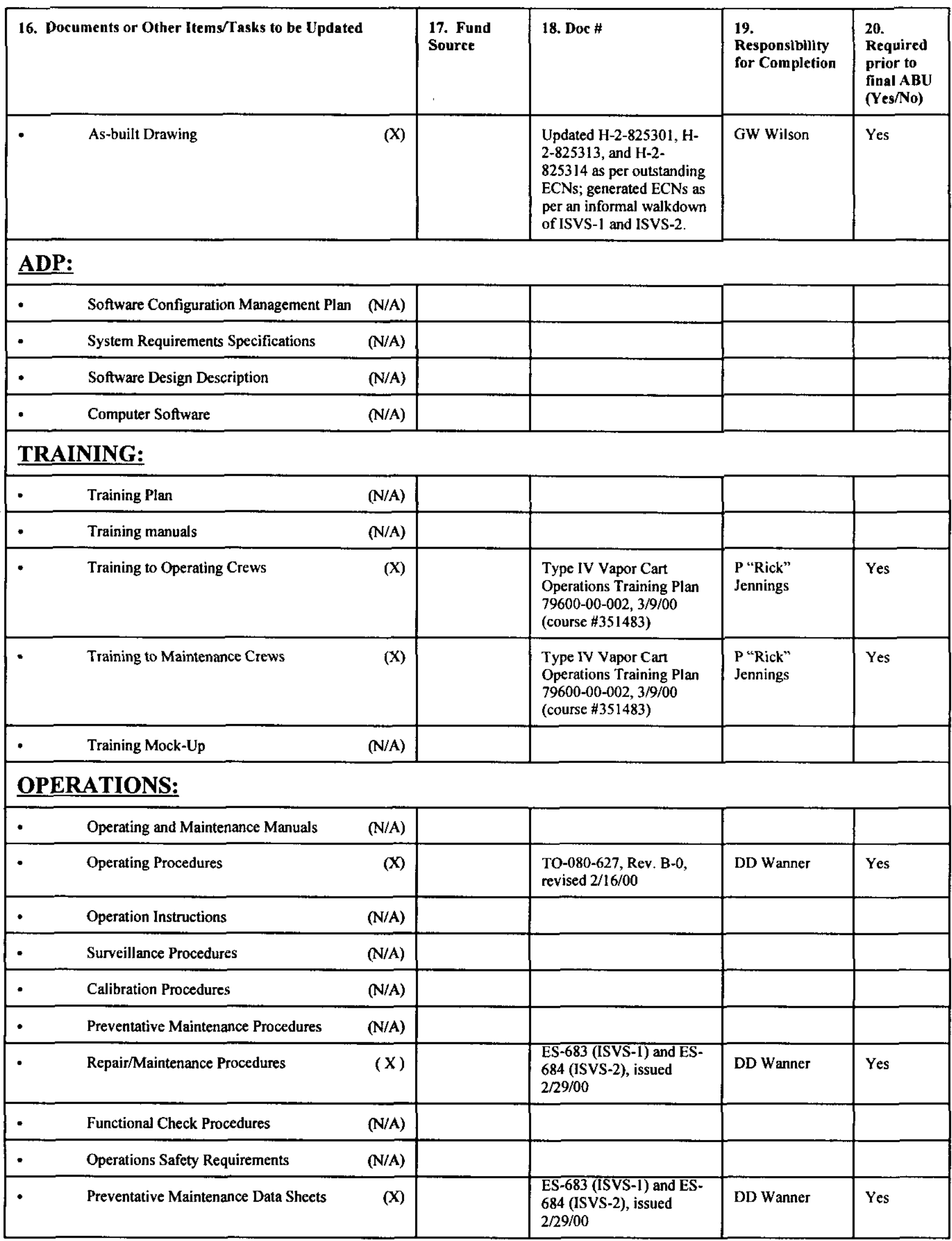


RPP-5451, Rev. 0

\begin{tabular}{|c|c|c|c|c|c|}
\hline \multicolumn{2}{|c|}{ 16. Documents or Other Items/Tasks to be Updated } & $\begin{array}{l}\text { 17. Fund } \\
\text { Source }\end{array}$ & 18. Doc \# & $\begin{array}{l}19 . \\
\text { Responsibility } \\
\text { for Completion }\end{array}$ & $\begin{array}{l}20 . \\
\text { Required } \\
\text { prior to } \\
\text { final ABU } \\
\text { (Yes/No) }\end{array}$ \\
\hline \multicolumn{6}{|c|}{ QUALITY ASSURANCE: } \\
\hline • & Inspection Plan & & $\begin{array}{l}\text { See work packages ES-00- } \\
00032 \text { (ISVS-I) and ES- } \\
00-00033 \text { (ISVS-2). }\end{array}$ & ML McElroy & \\
\hline - & QA Program/Project Plan & & & & \\
\hline - & QAP JP & & & & \\
\hline - & NEC Inspection & & $\begin{array}{l}\text { NEC Inspection Report } \\
\text { No. } 8189 \text { : } \\
\text { NEC Service Inspection } \\
\text { Authorization No. } 8175 \text {, } \\
1 / 26 / 00 \text { (ISVS-1) } \\
\text { NEC Service Inspection } \\
\text { Authorization No. } 8176 \text {, } \\
1 / 26 / 00 \text { (ISVS-2) }\end{array}$ & JD Criddle & Yes \\
\hline \multicolumn{6}{|c|}{ PROCUREMENT ACTIVITIES: } \\
\hline - & Vendor Information & & TBD & GW Wilson & Yes \\
\hline - & Material List & & & & \\
\hline - & Spare Parts & & $\begin{array}{l}\text { Part of the } 2101 \mathrm{HV} \\
\text { Inventory System }\end{array}$ & JS Schofield & Yes \\
\hline - & Purchase Requisition & & & & \\
\hline - & ALARA Management Worksheet & & & & \\
\hline • & 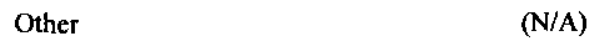 & & & & \\
\hline
\end{tabular}




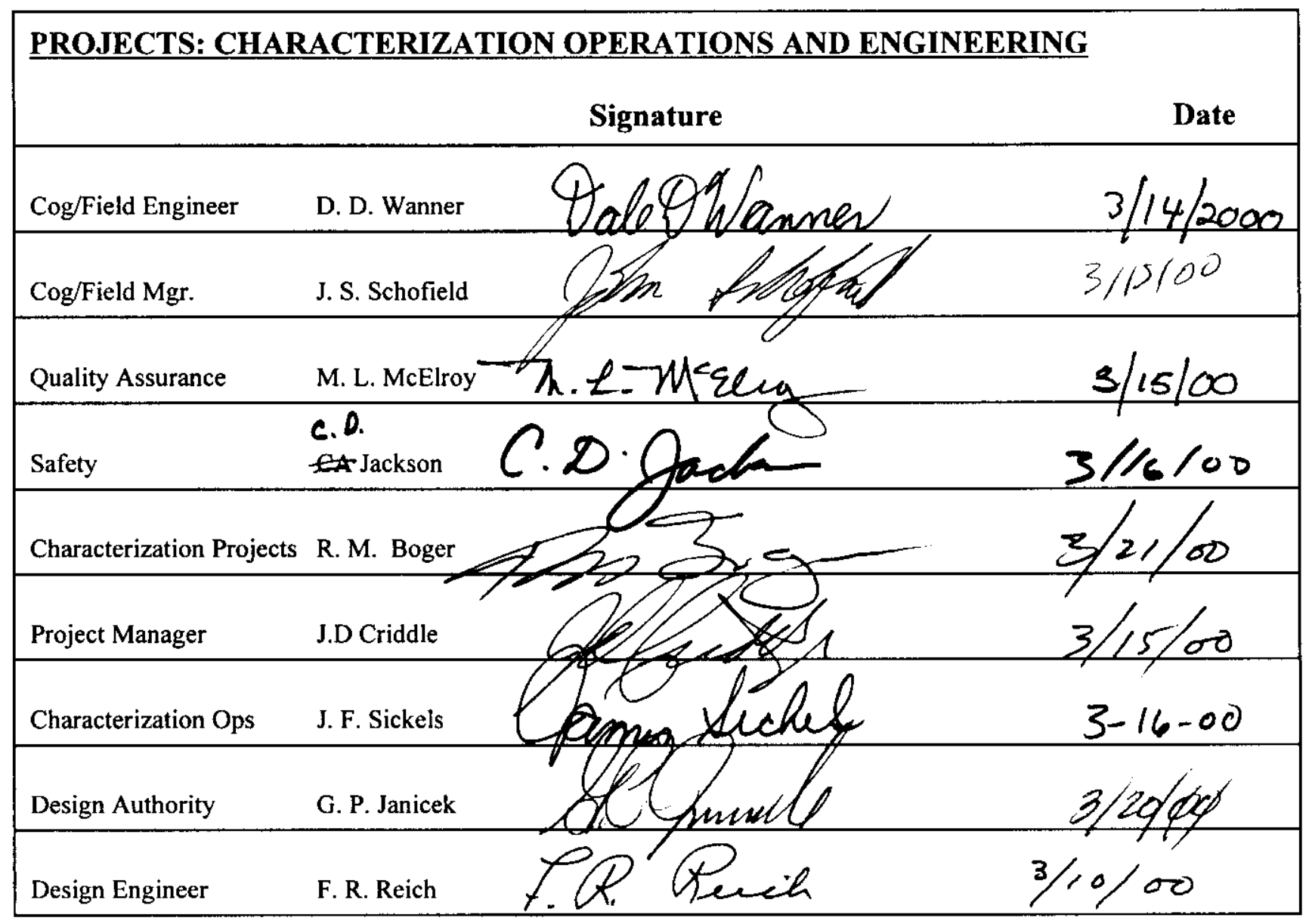

